\title{
Analysis of the technical condition of a railway bridge at risk of failure
}

\author{
Mieczysław Piechota ${ }^{1, *}$, and Grzegorz Rogojsz ${ }^{1}$ \\ ${ }^{1}$ Faculty of Civil Engineering and Geodesy, Military University of Technology, Warsaw, Poland
}

\begin{abstract}
The paper presents an analysis of the technical condition of a railway bridge structure with a span structure in the form of welded girders. Static diagram of the structure consists of two simply supported beams. The theoretical span of the spans is $2 \times 14.50 \mathrm{~m}$, their overall length is $14.90 \mathrm{~m}$, and the total length of the crossing is $30.6 \mathrm{~m}$. The reasons for the formation and development of bridge degradation were analysed. In addition, the actual load capacity of the structure was determined and the possibility of its further operation was evaluated. Particular attention was given to the quality of workmanship and the degradation progress of welded joints, which led to the exclusion of the object from use. The main purpose of the presented analyses is to formulate general recommendations, whose implementation in a direct or indirect form may contribute to reducing the degradation process of railway steel bridge structures. When inspecting welded railway bridges, particular attention should be paid to the condition of welds and to control and prevent the structure from cracking.
\end{abstract}

\section{Introduction}

Bridges are critical points in the infrastructure network and often decide on the usefulness and serviceability of that road network. Therefore, they should be designed and constructed in such a way that their durability is ensured in the assumed period of use as well as on the assumed maintenance level. This durability is defined as the ability to use and perform the structure while maintaining strength characteristics and operational features, which are measured by the ultimate limit states of resistance and limit states of use [1]. In Poland, there are over 35,000 bridges and tunnels on the public road network, of which $13.61 \%$ are steel bridges. The number of railway bridges is much more lower than the number of road facilities. According to [2], PKP Polskie Linie Kolejowe SA (Polish Rail Infrastructure Operator) there are approximately 8,000 rail bridges in Poland, of which $42 \%$ are steel bridges and steel viaducts. The issues of the life cycle of bridges enjoys the interdisciplinary interest of domestic and foreign specialists in the field of construction, mechanics, materials science, computer science and management [1]. At present, the endeavour for improvement of the diagnostic tools [3] as well as the development of a system for assessing the degree of degradation of bridges over time can be noted. These tools would have supported the assessment of the current technical condition and would have allowed the forecasting the

\footnotetext{
${ }^{*}$ Corresponding author: mieczyslaw.piechota@wat.edu.pl
} 
durability of bridge structures [4-14]. Properly carried out diagnostics of bridge structures and proper interpretation of the causes of damage and irregularities allows for the development and implementation of new structural solutions in bridge engineering [15] and innovative construction materials [16]. Currently, scientists are being focused on implementing systems that enable bridge management from the beginning of the design process, through construction and maintenance, to final demolition. This technology is called BIM (Building Information Modelling) and for the purpose of its proper development, it is necessary to improve the bridge management software to make the right decisions regarding the allocation of limited financial resources for maintenance works [17-19].

The article presents the methodology for assessing the technical condition of the selected railway bridge, which was classified as being excluded from use. This assessment was made based on the special inspection [20]. During the inspection of the structure, particular attention was paid to the measurement of the extent and depth of corrosion damages as well as the detection and assessment of the size and causes of cracks in the structure elements. This range of tests allowed to determine the actual geometric parameters of cross-sections and to determine the degree of weakening of the structure.

\section{Description of the technical condition of the bridge}

Presently, welded joints are most commonly used for new bridges. This results both from the ease of making elements, the smaller weight of the structure (in relation to the riveted spans) as well as from the precise control of the quality of the welds. The technology of welded bridges dates back to 1929, when the first welded bridge in the world was built for use, built on the Słudwia River based on the design of Professor Bryła. Due to the fact that this type of connection of elements is very sensitive to all defects and damages, only road bridges were originally made as welded. Railway bridges, whose loads are much larger than road bridges, had been started to weld in the post-war period. Bridge structures from that time had many defects that caused their accelerated degradation. The long-term observation of railway steel bridges with weldments $[1,2,19,20]$ has shown that the most common damage to structural elements in steel rail bridges with welded construction are:

- destruction of the material caused by changes of chemical and / or physical properties of the material, e.g. uniform (surface) corrosion, pitting corrosion, crevice corrosion, stress corrosion,

- material losses consisting in reducing the cross-sectional area of the element and partial or complete dysfunction of anti-corrosion coatings,

- cracks at the interface of joined elements,

- cracks consisting of loss of continuity of the entire cross-section of the element, resulting from sudden brittle destruction, brittle fatigue destruction or material fatigue,

- deformations - changes that are inconsistent with the design (permanent or unstable) of the geometry of the structure causing changes in the mutual distances of its points, occurring without changing the position of the entire structure or its part,

- impurities associated with the accumulation of organic and inorganic organisms on the surface of elements,

- changes in the position of elements resulting from improper positioning of elements, excessive linear displacement, excessive rotation, limitation of linear displacement and limitation of the possibility of rotation.

The assessed bridge was built in 1949. The supporting structure is made up of I-beam girders with a web connected to the flanges by means of butt welds [20]. The beam web is made of $1700 \times 12 \mathrm{~mm}$ sheet. The spar flanges are symmetrical with supports from sheets of $350 \times 20 \mathrm{~mm}$. The bottom flange in the middle of the span has a thickness of $30 \mathrm{~mm}$. The 
girders' web is stiffened with stiffeners spaced every $1.45 \mathrm{~m}$ on the entire length of the bridge. These stiffeners are welded to the girders by means of fillet welds. Transversal braces are made of crossed isosceles angles L $80 \times 80 \times 9$ and attached to vertical stiffeners with rivets. Wind braces are made of L $100 \times 100 \times 9 \mathrm{~N}$-shaped angles. In general, the condition of the welded structure of the girders has been defined as pre-failure. The corrosion damage of the span structure as well as the cracking of joined girders should be considered as the basis for this assessment. In places where the joints were concentrated, the material was often overheated, causing local intense corrosion, often leading to puncture of elements Fig. 1 [20].

a)

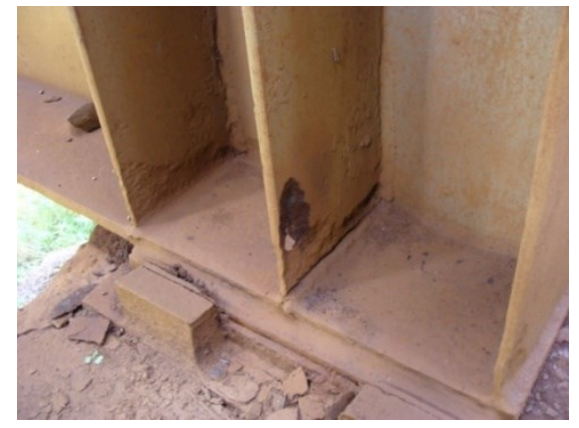

c)

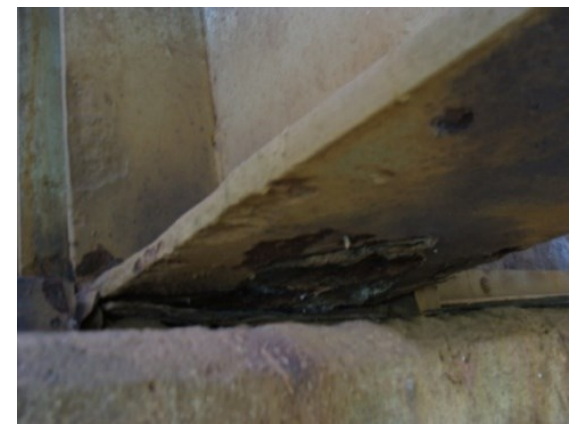

b)

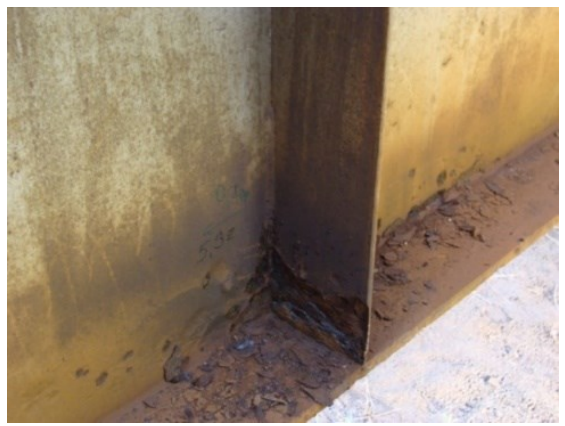

d)

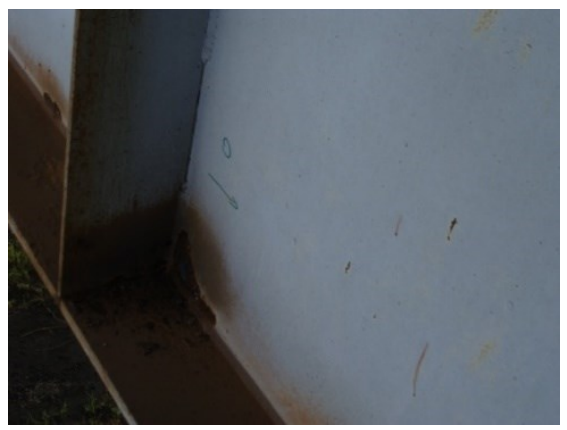

Fig. 1. Examples of corrosion damage in the place of overheating of elements during the welding of structures $a, b$ ) vertical ribs, c) lower flange, d) web.

The result of the inaccuracy of the welded joints are cracks, both along the weld as well as the elements next to them. One of the damages observed, often occurred in other welded constructions, are cracks in the weld connecting the bottom flange with the girder's web. This damage is a threat to the operational safety of the bridge. There is a real risk of a construction disaster by the losing of the stability of the main girders in the event of significant horizontal loads (e.g. from braking and acceleration forces). An example of this damage is shown in Fig. 2 a) b) [20]. 
a)

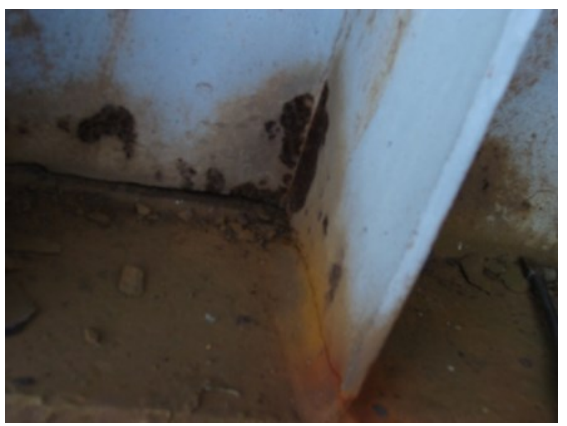

b)

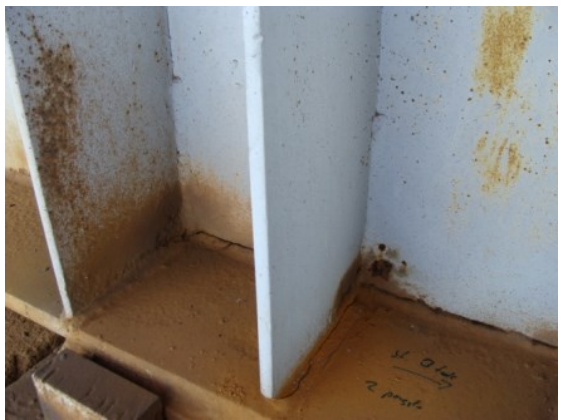

Fig. 2. Examples of damage to joints connecting the bottom flange with the girder web under track No. 2.

The general corrosion of this bridge is located primarily in joints of girders with bracing - Fig. 3 a) $\div$ d) [20]. Due to the lack of maintenance works, corrosion products maintain moisture and cause accelerated technical wear of the structure as well as the development of local corrosion in the form of deep pits and crevice corrosion.

a)

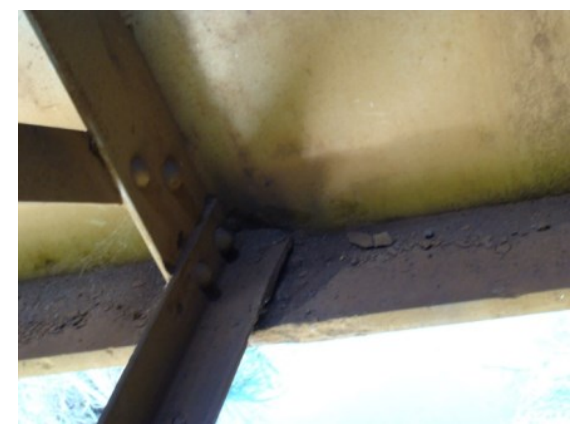

c)

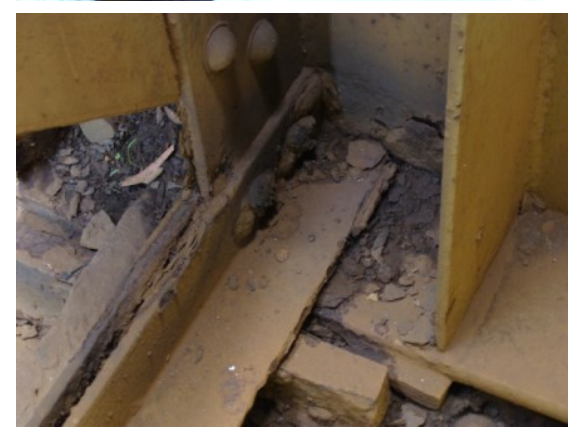

b)

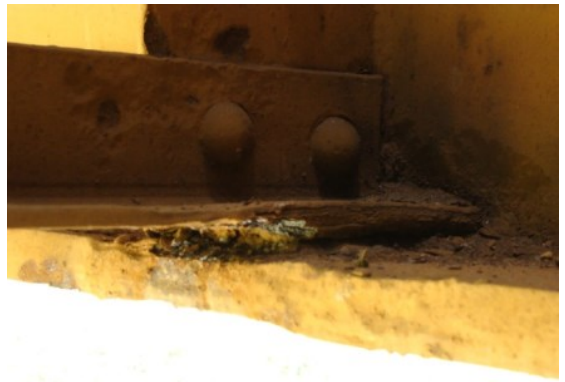

d)

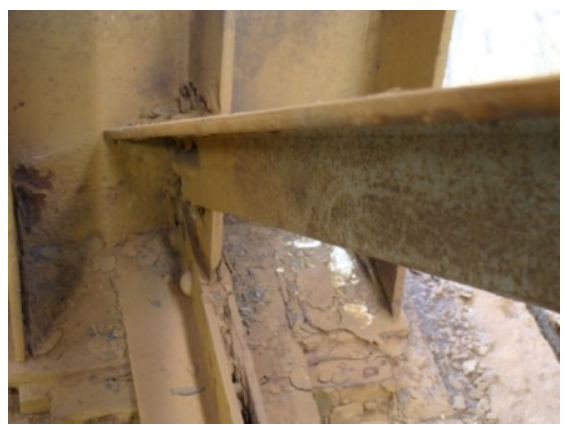

Fig. 3. Examples of corroded joints of girders and braces.

Corrosion damage of the gusset plates of the upper wind braces caused their complete failure. The thickness of the described elements is $\sim 3 \mathrm{~mm}$ - the corrosion has penetrated them locally - Fig. 4 a), b) [20]. 
a)

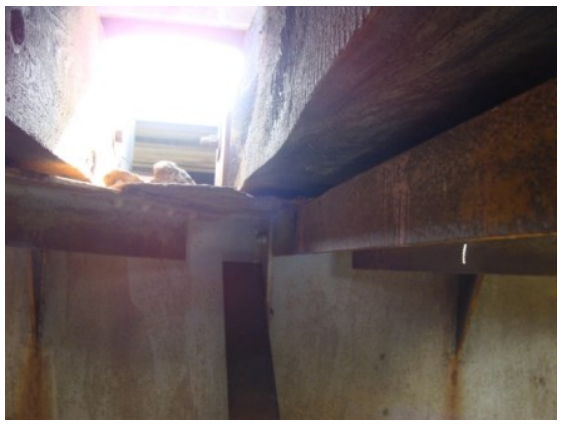

b)

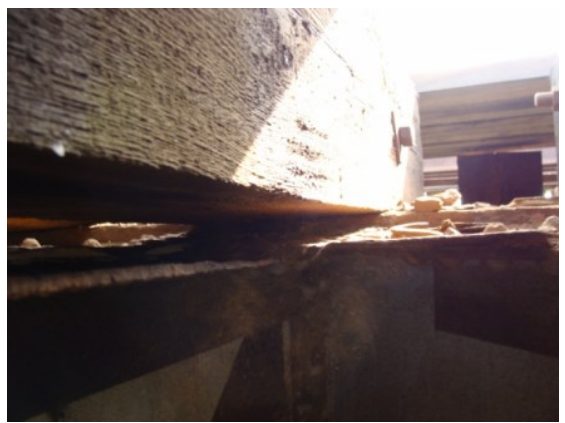

Fig. 4. Examples of damaged gusset plates of the upper span wind braces.

The direct support of wooden bridge sleepers on the top flanges of the spans without adequate protection has caused significant corrosion damage. The minimum measured thickness of the top flange was $10.6 \mathrm{~mm}$, which is approximately $50 \%$ of the initial value Fig. 5 a), b) [20]. These damages are concentrated at the outer edges of the spar flanges. They cause a significant loss of material (up to several dozen percent of the thickness of the top flange), which leads to weakening of the girder, and thus to a decrease in the bearing capacity of the span.

a)

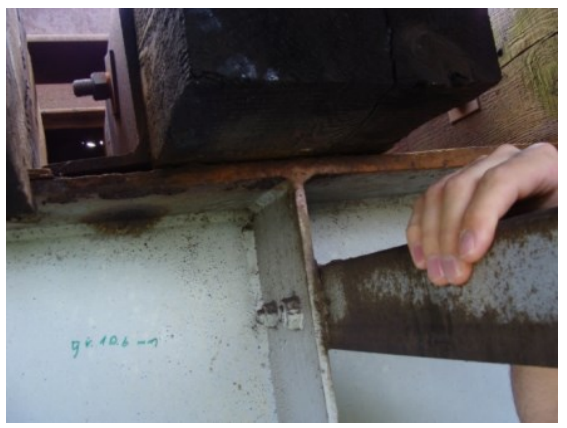

b)

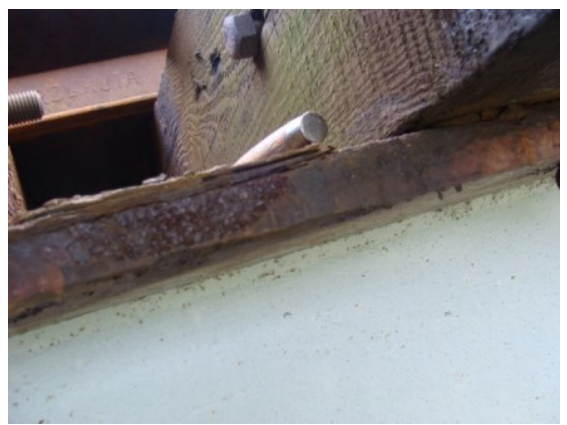

Fig. 5. Corrosion of the top flange causing a decrease in the load bearing capacity of the span.

The bridge deck is an open platform with bridge sleepers based directly on the upper longitudinal beams of the deck grate. Bridge sleepers are made of wood and have with a rectangular cross-section $27 \times 30 \mathrm{~cm}$ (fastened with screws). Some of them were diagnosed to be rotten or burnt. There was no presence of plates ensuring smooth rolling of derailed rolling stock and fire-proof sheets on the analysed object.

The abutments and the central pillar of the bridge are made of concrete. According to archival documentation they are based on pile foundations. No excessive displacements or deformations on the supports were observed that could indicate their improper behaviour under applied loads.

All spans of the analysed object are based on steel, tangent bearings. All bearings are surface corroded and their technical condition should be described as 'disturbing and alarming'. This assessment is due to the significant corrosion of all bearings.

The assessed bridge is equipped with wooden working platforms based on extended bridge sleepers. The condition of these platforms should be also described as 'disturbing and alarming'. Some of the deck boards are damaged and qualify for the replacement. There is no stairs on both abutment slopes, which makes inspection and ongoing maintenance of the bridge difficult. 
Due to the open deck, the bridge does not have a drainage system. However, it would be necessary to ensure rapid rainwater runoff from the footings of the bearings by cleaning them and giving them the appropriate inclination.

\section{Static structural analysis}

The deadweight of the span structure together with the pavement and equipment is $8,2 \mathrm{kN} / \mathrm{m}$. According to the assumptions for the inspection, the structure was checked for the operational load for the $k+2$ class.

The maximum characteristic values of internal forces are:

$$
\begin{gathered}
M_{\max }=215,5+2103,3=2318,8 \mathrm{kNm} \\
T_{\max }=59,5+580,2=639,7 \mathrm{kN}
\end{gathered}
$$

The system of basic loads was assumed for designing. The dynamic coefficient has the value:

$$
\varphi=\frac{1,44}{\sqrt{L}-0,2}+0,82=1,22
$$

where:

$L$ - span length [m]: $\quad L=14,5 \mathrm{~m}$

Considering the speed limit of $V=30 \mathrm{~km} / \mathrm{h}$ (speed limit on the bridge during the special inspection), the value of the dynamic coefficient is:

$$
\varphi_{n v}=1+\frac{\varphi-1,0}{70}(V-10)=1,06
$$

hence the design values of internal forces are:

$$
\begin{aligned}
& M_{\text {max }}=215,5 \cdot 1,2+2103,3 \cdot 1,5 \cdot 1,22=4107,64 \mathrm{kNm} \\
& M_{\text {max }}=215,5 \cdot 1,2+2103,3 \cdot 1,5 \cdot 1,06=3602,85 \mathrm{kNm}-\text { with speed limit } \\
& M_{\text {min }}=215,5 \cdot 1,2=258,60 \mathrm{kNm} \\
& T_{\max }=59,5 \cdot 1,2+580,2 \cdot 1,5 \cdot 1,22=1133,17 \mathrm{kN} \\
& T_{\text {max }}=59,5 \cdot 1,2+580,2 \cdot 1,5 \cdot 1,06=993,92 \mathrm{kN}-\text { with speed limit }
\end{aligned}
$$

The moment of inertia of the cross-section in the middle of the span is :

- for the undamaged cross-section: $J_{x}=1770012 \mathrm{~cm}^{4}$,

- for the damaged cross-section: $J_{x}=1534956 \mathrm{~cm}^{4}$.

The sectional modulus is :

- $\quad$ for the undamaged cross-section: $W_{x}=18616 \mathrm{~cm}^{3}$,

- for the damaged cross-section: $W_{x}=15208 \mathrm{~cm}^{3}$.

The determined value of stresses in the middle of the span of the structure from the design loads is:

- for the undamaged structure: $\sigma_{\max }=193,5 \mathrm{MPa}(220,7 \mathrm{MPa}$ - without speed limit),

- for the damaged structure: $\sigma_{\max }=236,9 \mathrm{MPa}(270,1 \mathrm{MPa}$ - without speed limit),

Assuming the allowable structural design strenght for built-in K37 steel (with parameters corresponding to St3M steel) $190 \mathrm{MPa}$, the determined stresses at the permissible operating speed are not exceeded for the analysed structure only without taking into account corrosion damage. However if we take into account the corrosion damage of the top flange, it will be possible to transfer normative loads only to the class $k=-1$, while maintaining the speed limit to $30 \mathrm{~km} / \mathrm{h}$. 
Then the tangential stresses in the support cross-section were analysed. This section originally consisted of six ribs (three symmetrical in the support zone) and the web. As a result of the crack in the area of the weld (with the lenght of aproximatelly $350 \mathrm{~mm}$ ) connecting the lower flenge of the girder with the web and the ribs in the support zone (see Fig. 2b), the transverse force is being transfered by two $12 \mathrm{~mm}$ thick ribs. The total crosssectional area of the support zone working at shear is $42 \mathrm{~cm} 2$. Hence the tangential stresses are:

$$
\tau_{\max }=137,9 \mathrm{MPa}>0,6 \cdot f_{y d}=114 \mathrm{MPa}
$$

It follows that due to the damage in the support zone, it is impossible to transfer loads from the braking force and acceleration of the rolling stock in accordance with the applicable standards $[21,22]$.

\section{Discussion}

Mechanisms of the corrosion damage of the steel bridges are presented in paper [1]. Identification of these mechanisms is important when making mandatory periodic inspections of the technical condition of bridges (legally required), including ongoing, basic, extended and detailed inspections [23], as well as expert opinions on the determination of causal links of operational failures and the disclosure of physical defects at the design and construction stage. The basic tests to be performed should include the determination of the degree of degradation of the structure (including measurements of corrosion losses), structural elements geometry and real parameters of materials used [1]. In the case of the analysed bridge structure, the following were particularly important for the assessment of the current load capacity:

- measurements of the range and depth of corrosion damage,

- determination of the degree of material loss in particular cross-sections, including their actual geometrical parameters,

- identification and assessment of the size and causes of cracks in structural elements.

The selection of elements and areas of the structure for testing and measurements as well as for sampling should always be determined individually for individual bridge [1]. It is also necessary to choose areas representative of the object, i.e. places of expected major internal forces. These sites should be determined on the basis of detailed computational analyses, in which the frequency and intensity of all possible permanent and variable loads should be taken into account.

The static structural analysis of the span structure under the track No. 2 allows to state that the welded bridge does not meet the requirements in the range of ultimate limit states for load class $\mathrm{k}+2(\mathrm{ak}=1.21)$. Modernization of this bridge structure is unprofitable because it involves the renewal of a damaged top flange. 


\section{Conclusions}

The damage to the assessed railway bridge described above posed a threat to its safety. There was a real threat of a structure failure by losing the stability of the main girders. Therefore, immediate action was taken to exclude this bridge structure from use. As a result, the span structure was changed to the steel box girder and the support system was adopted to the proposed girder solution - Fig. 6 a), b).

a)

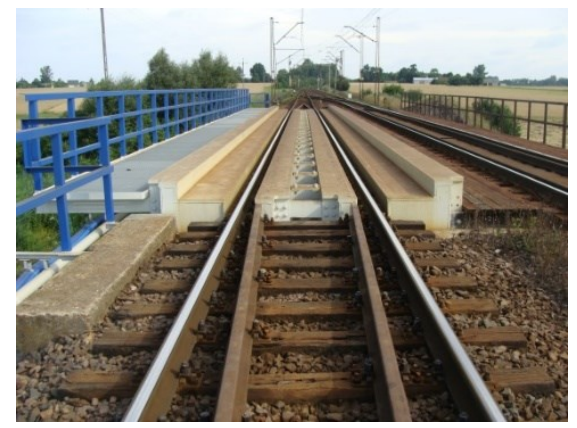

b)

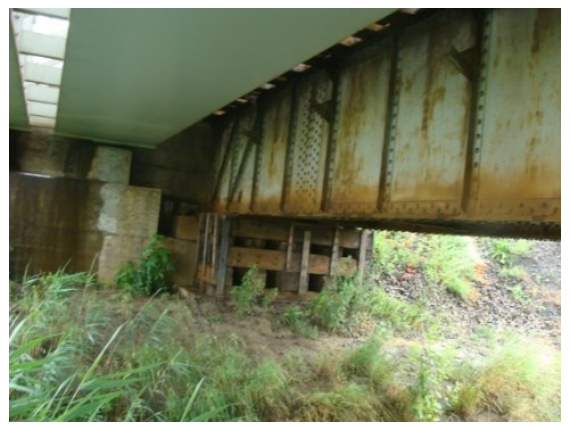

Fig. 6. The bridge after replacement of span structure, a) top view, b) bottom view with modernized support (under the renewed span).

The development of a proper and full assessment of the technical condition of steel railway bridges requires consideration of many operational factors, ranging from the assessment of the quality of maintenance to the degree of wear of the structure elements and the extent of damage to this elements. Before conducting the inspection, it is necessary to analyse the accessible documentation of the bridge and carry out local site inspection. The last but not least abovementioned step is often omitted, which may result in an incorrect determination of the inspection scope and elements to be assessed. Without a field "in-situ" inspection it is very difficult to select possible elements and areas of the structure for testing and to choose the best and the most appropriate methods and suitable techniques for conducting that inspection.

The results of the conducted analysis and the technical condition of the structure indicated that the scope of the possible renovation should include:

- replacement of heavily corroded top flanges,

- replacement of the stiffeners and repair of welds connecting the web with the bottom flange in the support zone,

- local replacement of parts of the bottom flange,

- replacement of gusset plates and wind braces,

- replacement of the entire railway track combined with the track alignment.

Moreover, due to the corrosion damage to bearings, it would be necessary to carry out renewal of these elements and to perform a new protection with anti-corrosive coatings of the entire bridge structure. The presented scope of repair works and technical wear (including the effect of material fatigue) caused that the modernization of the span structure was unprofitable - hence the span was dismantled. 


\section{References}

1. L. Więcław, W. Moćko, R. Chmielewski, L. Kruszka, Roads and Bridges - Drogi i Mosty, 15(4), pp. 315-328 (2016)

2. J. Bień, Damages and diagnostics of bridge structures, (Wydawnictwo Komunikacji i Łączności, Warszawa 2010) [in Polish]

3. M. Szudyga, Zeszyty Naukowe Wyższej Szkoły Zarządzania Ochroną Pracy w Katowicach, 1(7), pp. 123-134 (2011) [in Polish]

4. J. Bień, K. Jakubowski, T. Kamiński, J. Kmita J, P. Rawa, P. Cruz, M. Maksymowicz, [in:] Sustainable Bridges - Assessment for Future traffic Demands and Longer Lives (Wrocław, pp. 105-116, 2007)

5. J. Bień, M.J. Kużawa, Progress in steel and composite structures (Proceedings of the 12th International Conference on Metal Structures, Wrocław 2011)

6. H. Czudek, A. Wysokowski, Durability of road Bridges (Wydawnictwo Komunikacji i Łączności, Warszawa 2005) [in Polish]

7. D.N. Farhey, R. Naghavi, A. Levia, A.M. Thakur, M.A. Pickett, D.K. Nims, A.E. Aktan, J. Bridge Eng., 5(1), 39-48 (2000) [in Polish]

8. B. Kühn, M. Lukic, A. Nussbaumer, H.P. Günther, R. Helmerich, S. Heroin, M.H. Kolstein, S. Walbridge, B. Androic, O. Dijsktra, B. Bucak, Assessment of Existing Steel Structures: Recommendations for Estimation of Remaining Fatigue Life (JRC Scientific and Technical Reports, 2008)

9. B.J. Little, P.A. Wagner, F. Mansfeld, Int. Mater. Rev., 36, pp. 253-272 (1991)

10. A. Wysokowski, Trwałość mostów stalowych $w$ funkcji zjawisk zmęczeniowych i korozyjnych (Instytut Badawczy Dróg i Mostów, Studia i Materiały, 53, 2001) [in Polish]

11. A. Wysokowski, Zmęczenie i korozja - wyznacznik trwałości eksploatacyjnej mostów stalowych, Mosty stalowe. Projektowanie, technologie budowy, badania, utrzymanie (Wrocławskie Dni Mostowe, Wrocław, pp. 369-379, 2008) [in Polish]

12. H. Zobel, T. Alkhafaji, M. Wróbel, Mosty, 2, pp. 40-54 (2007) [in Polish]

13. L. Kruszka, A. Miyamoto, Mosty, 2, pp. 12-21 (2011) [in Polish]

14. R. Chmielewski, L. Kruszka, W. Młodożeniec, Biuletyn WAT, 53 (2004) [in Polish]

15. G. Łagoda, M. Łagoda, Nowoczesne Budownictwo Inżynieryjne, VII-VIII, pp. 36-41 (2007) [in Polish]

16. S. Nakamura, Struct. Eng. Int., 1, pp. 45-50 (2000)

17. J. Bień, Zeszyty Naukowe Politechniki Rzeszowskiej, 59, 49-68 (2012) [in Polish]

18. J. Bień, P. Rawa, B. Bień, Inżynieria i Budownictwo, 11, 669-672 (2001) [in Polish]

19. J. Bień, Modeling of bridges in the process of their operation (Oficyna Wydawnicza Politechniki Wrocławskiej, Wrocław 2002) [in Polish]

20. R. Chmielewski, L. Kruszka, Ekspertyzy, opinie techniczne z zakresu budownictwa, (WAT, Warszawa, 2005-2018) [in Polish]

21. EN 1993-1-2:2006 - Eurocode 3: Design of steel structures - Part 2: Steel Bridges

22. PN-EN 1991-2:2007: Actions on structures - Part 2: Traffic loads on bridges.

23. Instruction for maintenance of railway engineering structures on railway lines up to 200/250 km/h, Id-16, Annex to Resolution No. 48/2014 of the PKP PLK Management Board of December 1, 2014 [in Polish]. 